\title{
IMPACT OF LEGAL AND ADMINISTRATIVE ISSUES ON THE SUCCESS OF FEMALE MICRO ENTREPRENEURS IN PESHAWAR, KHYBER PAKHTUNKHWA, PAKISTAN
}

\author{
Rafa Mushtaq* \& Prof. Dr. Ghazala Yasmeen $\dagger$
}

\begin{abstract}
The women entrepreneurs play a very vital role in the economy of a country. The small enterprises run by women entrepreneurs at micro-level make a great contribution in the market by introducing various innovative ideas, products and services for the people. On the other hand, women face issues in accessing education, training and other services because the free market mechanism does not provide isolated openings for women. Women have to compete for and work in the same existing and regulatory framework as their counterpart does so. The situation compels a deeper understanding of the gender prejudices that has become the confining factors for women in accessing and availing business opportunities and active participation. In Pakistan, society several societal, cultural, traditional and religious elements have made the environment more complicated for women, particularly in the field of business sector. The existing environment is a legacy of patriarchal system that believes in no women participation in the outer world. In other words, women in such societies have no say in decision making and are not allowed to have economic independence.
\end{abstract}

\footnotetext{
* M.Phil. Scholar, University of Peshawar, Email: rafamushtaq110@gmail.com

$\dagger$ Women University Mardan, Email: ghazala_nizam2006@yahoo.com
} 
Keywords: Legal and administrative issues, vital, prejudices, legacy, economic independence, Female Micro Entrepreneurs, Peshawar Khyber Pakhtunkhwa Pakistan

\section{Introduction}

The definition of the term "Entrepreneur" can be attributed to the French Economist who used the word in the meaning of "economic agent" in 1803. An economic agent represents wholesum of all assets, means of production including earnings. It also includes profits after all expenses are covered and rents are paid ((Bjerke, 2013). Later, many more dimensions were included in the study and the prospects of the concept of entrepreneurship were broadened. Because of the wide acknowledgements as a key aspect of economic energy, it gained significance in economic development, productivity, innovation, service and employment. Despite the significance and importance, the relationship between gender and entrepreneurship is complicated. Since, genders have different capabilities, skills, talents and aptitudes towards business. Male and female members of the family have their defined roles and particular behavior regarding religion, socio-cultural norms and values. From the very beginning, women in the society are defined in discriminatory terms of mental and physical abilities and thus, are assigned roles that are not promising. Typically, a woman is supposed to maintain her home and take care of her children and family. But in modern times, the women are also expected to face challenges of day to day life and to keep pace with the men. Given these expectations, women have become significant factor in socio economic development of a country. Conversely, in this research, the main emphasis remains on the women entrepreneurs as the scope of "Femaleness" has broadened in recent times.

The work trends and earnings opportunities are changing with time and the economic development. In Pakistan's context in general and in Khyber Pakhtunkhwa in particular, the economic development and the complexities of life are shaping the attitude towards women. It has become very difficult for one earning hand i.e. head of the family to provide for the entire family alone. Thus, all members of earning age must come forward and share the burden in order to live a standard life. Hurdles for women from family, society, legal norms and social values are still visible, and will continue for decades to come. But, the emergence of women as entrepreneurs have also given birth to the new and innovative ideas and products in the market (ILO, 2008; Yasmeen, 2004; Goheer, 2003). Women entrepreneurship has now been accepted and acknowledged everywhere in the world but still some 
factors are there, which are hindering them to flourish with all their potential and full zeal in Khyber Pakhtunkhwa province of Pakistan. This research has found the constraining factors towards the success for the women entrepreneurs at micro level.

Women enterprises have seen a quick development over the past 30 years. The field is in youth organizations because a plethora of impressive number of diary articles, writing audits and books being distributed on women business people with a twofold objective. First, a review was made into number of papers related to entrepreneurship published and distributed in journals from 1900 onward. Secondly, the prospects for entrepreneurship was assessed by particularly checking on writing surveys distributed from 1980 onward and put forwarded for future bearings. The findings of the study recommends a solid hypothetical base to investigate more on women enterprise (V. Yadav, 2016).

The later improvements of women entrepreneurship in Asian developing nations has made it exceptionally vital to reduce destitution in connection to business entrepreneurships and better employment opportunities. Because the representation of women in business environment is moderate, this can be credited to variables such as need of capital and lack of education.

The women of 21st century is contributing towards the development of economy and advancement of their socio-economic conditions. They have appeared with mind blowing effect on all segments of the economy. They are entering in the trade world due to progressed instruction level, standard of living and benefits at standard with their male partners. India, though far ahead than Pakistan, is also having more or less the same situation in terms of business opportunities for women. Therefore, many efforts are needed in order to fill the vacuum related to fabricating and work issues confronted by ladies as entrepreneurs or those interested in the field (Singh, 2015).

\section{Objectives}

The study is carried out to achieve the following specific objectives to describe the role of women in entrepreneurial process, and to determine the key economic, social, legal and administrative factors that affect the performance of women entrepreneurs.

- To describe the role of women in entrepreneurial process.

- To determine the key economic, social, legal and administrative factors that affect the performance of women entrepreneurs. 
Hypothesis: The hypothesis of the study are:

$\mathbf{H}_{\mathbf{O}}$ : Legal and administrative issues make female entrepreneurs hesitant to enter into the business.

$\mathbf{H}_{1:}$ Legal and administrative issues do not make female entrepreneurs hesitant to enter into the business.

\section{Material and Methods}

The in-depth interview method was used. The self-structured questionnaire comprises of both quantitative and qualitative questions. Data was collected from women entrepreneurs in Peshawar because the Peshawar district is the capital of the province and has a large number of women entrepreneurs, working at micro level. This diverse group of entrepreneurs are engaged in heterogeneous as well as homogeneous business activities. The sample size included 100 women entrepreneurs who were randomly selected from Peshawar, Khyber Pakhtunkhwa in the following manner:

\begin{tabular}{|l|c|c|}
\hline \multicolumn{1}{|c|}{ Organization } & Status & Sample Size \\
\hline Women Business & Registered & 50 \\
Development Centre & & \\
(WBDC), SMEDA & & 30 \\
\hline KP Women & Registered & \\
Entrepreneurship Centre, & & \\
Women Chamber of & & \\
Commerce & & 20 \\
\hline $\begin{array}{l}\text { Other Women } \\
\text { Entrepreneurs Working in } \\
\text { Peshawar }\end{array}$ & Un-registered & \\
\hline Total & & 100 \\
\hline
\end{tabular}

\section{Research Model}

Dependent Variables

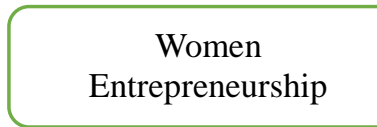

\section{Independent Variables}

Legal and administrative issues

Hypothesis: Legal and Administrative issues make female entrepreneurs hesitant to enter into the business. 
The legal and administrative issues mainly include the bureaucratic system and red tapes of the organizations. Though Peshawar is the capital of Khyber Pakhtunkhwa province but has a conservative environment for females. They are not encouraged to be very mobile in the society. Most of the government departments like taxation office and other are the areas where women do not want to go by themselves due to their male dominant culture. Women entrepreneurs are therefore, reluctant to start their businesses to avoid the legal and administrative systems i.e. legal and administrative issues are negatively correlated with the women entrepreneurship.

Association of Income with Bureaucracy and Red Tapes: In this section woman entrepreneurs were asked whether their income is affected by delays and problems regarding bureaucratic systems and red tapes i.e. unnecessary delaying of tasks while going through the registration or other producers related to their businesses.

\section{(a) Income * Bureaucracy and Red Tapes}

Chi-Square Tests

\begin{tabular}{|l|c|c|c|}
\hline & Value & Df & $\begin{array}{c}\text { Asymptotic Significance } \\
\text { (2-sided) }\end{array}$ \\
\hline Pearson Chi-Square & $36.169^{\mathrm{a}}$ & 8 & .000 \\
\hline Likelihood Ratio & 38.380 & 8 & .000 \\
\hline $\begin{array}{l}\text { Linear-by-Linear } \\
\text { Association }\end{array}$ & 19.494 & 1 & .000 \\
\hline N of Valid Cases & 99 & & \\
\hline
\end{tabular}

a. 9 cells $(60.0 \%)$ have expected count less than 5. The minimum expected count is 1.62 .

The table represents the Chi-Square results of association of Income with bureaucracy and red tapes never faced is $(\mathrm{X} 2(2, \mathrm{~N}=100)=36.169, \mathrm{P}<$ 0.005). The results found that there is a strong association between the income and bureaucracy and red tapes never faced. The result is highly significant, so we accept it. 
Impact of Legal and Administrative Issues on the Success

\section{Income * Bureaucracy and Red Tapes}

\begin{tabular}{|c|c|c|c|c|c|c|}
\hline \multirow[t]{2}{*}{ Income } & \multicolumn{5}{|c|}{ Bureaucracy and Red Tapes } & \multirow[t]{2}{*}{ Total } \\
\hline & 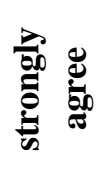 & 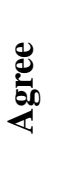 & 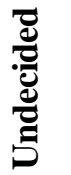 & 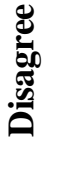 & 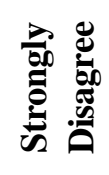 & \\
\hline $20,000-59,000$ & 2 & 1 & 1 & 9 & 21 & 34 \\
\hline $60,000-79,000$ & 0 & 2 & 2 & 8 & 20 & 32 \\
\hline 80,000 -above & 3 & 11 & 9 & 4 & 7 & 34 \\
\hline Total & 5 & 14 & 12 & 21 & 48 & 100 \\
\hline
\end{tabular}

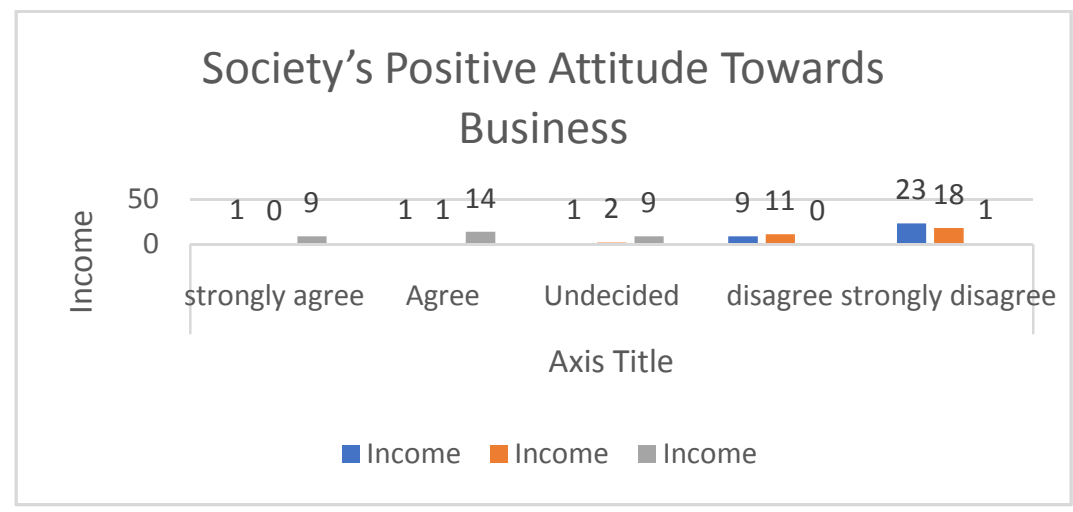

\section{Income * Bureaucracy and Red Tapes}

The results obtained illustrate that the women entrepreneurs whose income range is from 20,000-59,000, 21 respondents strongly disagree, 9 respondents disagree, 1 respondent choose undecided, 1 respondents agreed and 2 respondents strongly agreed with idea that society's attitude towards their business is positive, the women entrepreneurs whose income range is from $60,000-79,000,20$ respondents strongly disagree, 8 respondents disagree, 2 respondents choose undecided, 2 respondents agreed and 0 respondents strongly agreed with the idea that society's attitude is positive towards their business whereas the women entrepreneurs whose income range from 80,000 and above, 7 respondents strongly disagree, 4 respondents disagree, 9 respondents choose undecided, 11 respondents agreed and 3 respondents strongly agreed respectively. 
Association of Income with Unfavorable Legal and Administrative Environments: In this section women entrepreneur's income was taken as a dependent variable and the unfavorable legal and administrative environments were taken as independent variable in order to determine the association between them.

\section{(a) Unfavorable Legal and Administrative Environments}

Chi-Square Tests

\begin{tabular}{|l|c|c|c|}
\hline & Value & df & $\begin{array}{c}\text { Asymptotic } \\
\text { Significance (2-sided) }\end{array}$ \\
\hline Pearson Chi-Square & $35.804^{\mathrm{a}}$ & 8 & .000 \\
\hline Likelihood Ratio & 36.922 & 8 & .000 \\
\hline $\begin{array}{l}\text { Linear-by-Linear } \\
\text { Association }\end{array}$ & 20.019 & 1 & .000 \\
\hline N of Valid Cases & 99 & & \\
\hline
\end{tabular}

a. 7 cells $(46.7 \%)$ have expected count less than 5. The minimum expected count is 1.94 .

The Chi-Square results of association of Income with unfavorable legal and administrative environments is $(\mathrm{X} 2(2, \mathrm{~N}=100)=35.804, \mathrm{P}<0.005)$. Hence, there is a strong association between the income with unfavorable legal and administrative environments.

(b) Unfavorable Legal and Administrative Environments

\begin{tabular}{|c|c|c|c|c|c|c|}
\hline \multirow[t]{2}{*}{ Income } & \multicolumn{5}{|c|}{$\begin{array}{c}\text { Unfavorable Legal and } \\
\text { Administrative Environments }\end{array}$} & \multirow[t]{2}{*}{ Total } \\
\hline & 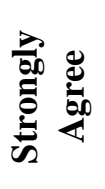 & 递 & 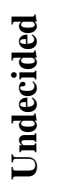 & 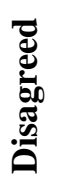 & 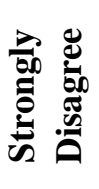 & \\
\hline $20,000-59,000$ & 2 & 1 & 1 & 9 & 21 & 34 \\
\hline $60,000-79,000$ & 1 & 1 & 3 & 8 & 20 & 33 \\
\hline 80,000 -above & 3 & 13 & 7 & 4 & 6 & 33 \\
\hline Total & 6 & 15 & 11 & 21 & 47 & 100 \\
\hline
\end{tabular}




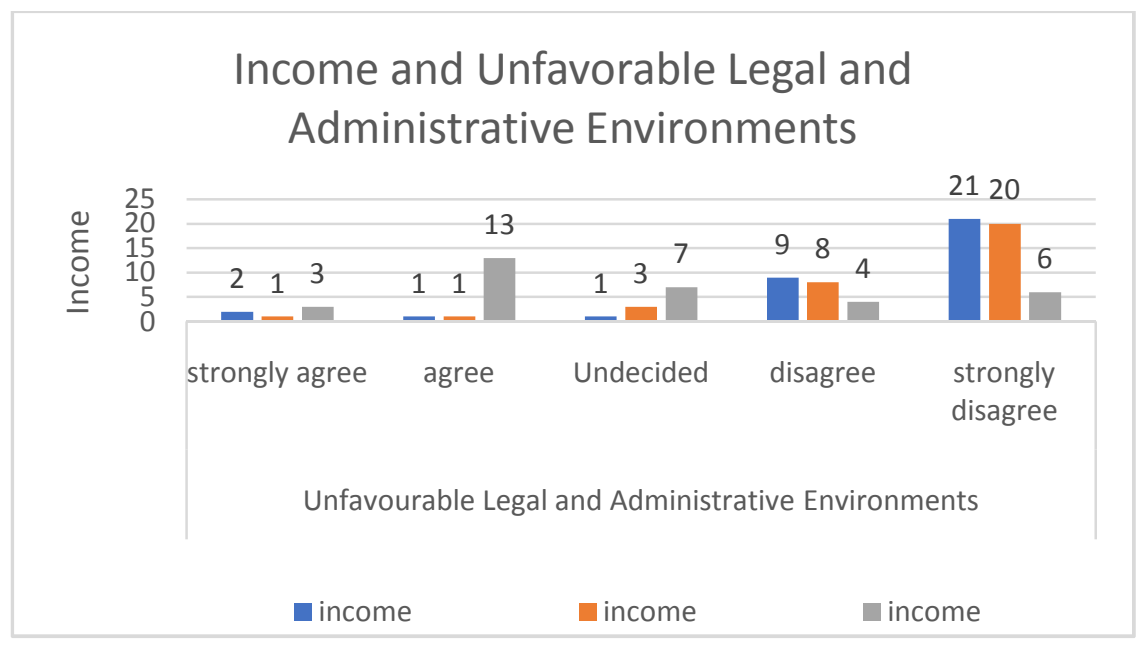

\section{Unfavorable Legal and Administrative Environments}

The table and the graph illustrate that the women entrepreneurs whose income range is from 20,000-59,000, 21 respondents strongly disagree, 9 respondents disagree, 1 respondent choose undecided, 1 respondent agreed and 2 respondents strongly agreed with idea that society's attitude towards their business is positive, the women entrepreneurs whose income range is from $60,000-79,000,20$ respondents strongly disagree, 8 respondents disagree, 3 respondents choose undecided, 1 respondent agreed and 1 respondent strongly agreed with the idea that society's attitude is positive towards their business whereas the women entrepreneurs whose income range from 80,000 and above, 6 respondents strongly disagree, 4 respondents disagree, 7 respondents choose undecided, 13 respondents agreed and 3 respondents strongly agreed respectively.

More than 67 percent of the population strongly disagree that they have never faced any unfavorable legal and administrative issues.

From the above discussion and calculation, it was found that there is a strong association among income, bureaucracy and red tapes. Similarly, a strong association between income and unfavorable legal and administrative conditions which negatively influence the women entrepreneurship, so we also accept our second hypothesis i.e. Legal and Administrative issues make female entrepreneurs hesitant to enter the business. 


\section{Conclusion and Recommendations}

The findings have indicated that in Khyber Pakhtunkhwa Province women entrepreneurs are facing many problems and challenges in the form of cultural norms, traditions, legal and administrative issues. The main reason is that in 2018, women are still considered as the symbol of the honor and people do not tolerate that they are working outside; though the level of acceptance has arisen and female entrepreneurs are working, but they have many problems such as the limitation of the resources, lack of education, lack of acceptance from the society, lack of facilities, security and safety issues etc. Hence, it is suggested that the Government should stretch priority to the problems faced by the women entrepreneurs and should provide them the opportunities such as the provision of the loan on easy terms and conditions. Government should ensure the provision of the education and training facilities, providing the legal help to the women entrepreneurs etc. The government is needed to take the effective steps to promote the women entrepreneurship in Khyber Pakhtunkhwa Province. It is important for the Government to create awareness between the people of the society that there is no issue if the women are involved in the different entrepreneurship activities. Religious scholars and the other educated people could play a positive role in this context.

\section{References}

Afza, T., \& Amir Rashid, M. 2009. Marginalized women social well-being through enterprise development: A glimpse of remote women status in Pakistan. Journal of Chinese Entrepreneurship, 1(3), 248-267.

Alam, A. 2012. Women Role and Status in Pukhtoon Society (A Case Study of Village Sufaid Dheri, Peshawar). International Journal of Learning and Development, 2(3), 313-324.

Anne Kovalainen, Johanna Österberg $\square$ Högstedt. 2013. Entrepreneurship within social and health care. International Journalof Gender and Entrepreneurship 5:1, 17-35.

Dafna Kariv, Susan Coleman. 2015. Toward a theory of financial bricolage: the impact of small loans on new businesses. Journal of Small Business and Enterprise Development 22:2, 196-224.

Eric Knight, Will Harvey. 2015. Managing exploration and exploitation paradoxes in creative organisations. Management Decision 53:4, 809-827.

Goheer, N. 2003. Women Entrepreneurship in Pakistan: How to Improve their Bargaining Power, ILO, Geneva. 
John Breen. 2010. Gender differences in home-based business ownership. Small Enterprise Research 17, 124-136.

Women Entrepreneurs a study of current status challenges and future perspective in the state of Himachal Pradesh by Singh Mr. Ranbir, 2015

Women entrepreneurship: research review and future directions by Vanita Yadav, 2016 (Journal of Global Entrepreneurship Research)

Yasmeen G. 2006. Formal and Informal Sector Micro Enterprises and their Linkages with the Rest of the Economy, 23-25. 